\section{Swapping Ilford for Baghdad}

\author{
Iraq's health minister, Dr Khudair Abbas, is \\ determined to transform Iraq's health services \\ even though it leaves him exposed to danger
}

Iraq's interim health minister, Dr Khudair Abbas-like any other Iraqi working closely with the US led Coalition Provisional Authority-is a natural target for attacks.

Far from the east London suburbs, where the 54 year old worked as a general and orthopaedic surgeon until he was appointed to Iraq's ministerial council in September, his four mile journey to work in Baghdad is a reminder that he can never feel safe. surgeon's post at King George Hospital in Ilford, east London. He returned home for the first time last year, shortly before his appointment as minister.

Now Dr Abbas, a member of Iraq's Dawa Islamic party, is heading one of the world's biggest and most ambitious health projects: the reconstruction of Iraq's collapsed public health system.

Once the jewel in the crown of health care in the Middle East, the system benefited from some
Dr Abbas said that only those loyal to the regime were provided with adequate care.

The chaos and anarchy that followed the US led occupation last spring finally brought the system to its knees, as the country's 240 hospitals and 1000 primary health centres were looted and destroyed and doctors kidnapped.

Dr Abbas's job was to kickstart Iraq's collapsed health service. He first tackled the high maternal and child death rates by giving priority to primary health care for women and children.

Then he set up new systems for importing pharmaceuticals as the United Nations' Oil for Food programme had ended. Soon, however, these heavily subsidised medicines found their way on to the black market. Corruption is a major problem.

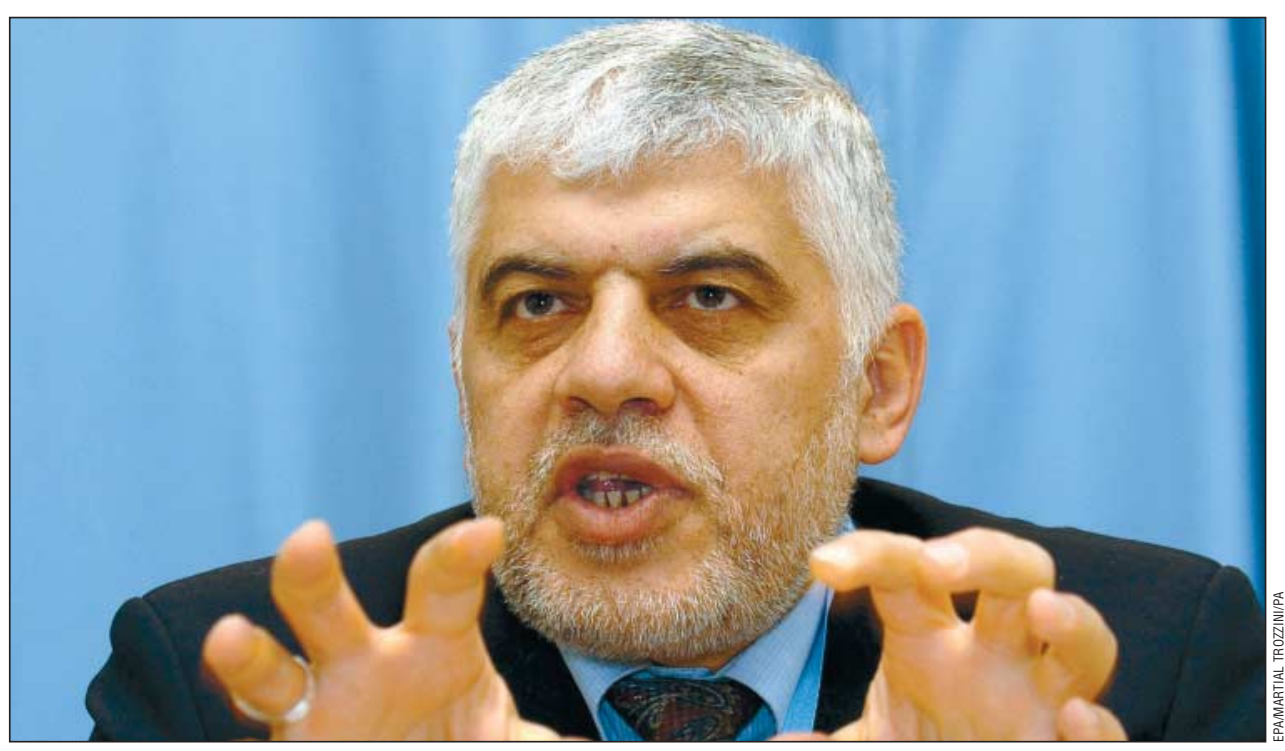

Even if a few of the 2000 Iraqi doctors working in Britain returned, says Dr Khudair Abbas, it would be "mercy from heaven"

"There are guards at home. I travel to the ministry in a convoy, taking different routes and different timing," Dr Abbas said in an interview in Geneva, where he was attending the World Health Assembly. "Constant awareness of security has become part of my life," he added.

Dr Abbas was born and raised in the southern city of Basra. He qualified at the University of Baghdad in 1972 and came to Britain in 1979, where he became a fierce opponent of the Iraq-Iran war, which led to his 23 years' exile.

In 1990, he became a fellow of the Royal College of Surgeons, Edinburgh, and took up a of the region's best doctors, many of whom trained in Britain.

But since Saddam Hussein came to power in 1979 , the system has been ravaged by three wars and gross underinvestment, particularly under United Nations' sanctions.

Iraq's health budget was reduced by $90 \%$ as spending shifted to the military and state security and the building of sumptuous palaces.

Mismanagement and abuse were systematic. Saddam Hussein accorded his favourite doctor the hereditary title "surgeon for life" and is said to have boarded up the windows of one hospital with sheets of steel to prevent patients viewing a nearby palace.
Other priorities have been the vaccination of the country's 4.2 million children against poliomyelitis, tetanus, diphtheria, measles, and tuberculosis; the distribution of medicines; and the fight against diseases such as malaria and cholera, which are endemic in parts of Iraq.

The Madrid donor conference last October won Iraq \$31bn (£17.3bn; €25.8bn), part of which was allocated to Dr Abbas's plans to rebuild the health system and to the occupied country's immediate public health needs-both of which were drawn up in collaboration with the World Health Organization and the Coalition Provisional Authority in Iraq (BMJ
2003;327:889). But the security situation has since become so bad that construction costs have spiralled beyond his original projections and there is an acute shortage of building materials.

The mainstay of the Iraqi health system is a planned chain of 220 new primary healthcare centres across the country, which Dr Abbas says will tackle $70 \%$ of Iraq's health needs. But with Iraq's current state budget, less than half of those can be built.

After decades of isolation, Iraq's 32000 doctors and medics need to update their knowledge. Dr Abbas has asked the British government to help by seconding from the NHS to Iraq 100 of an estimated 2000 Iraqi doctors working in Britain for a year, at a cost of $£ 60 \mathrm{~m}$ to $£ 100 \mathrm{~m}$. Even if a few of them return to help, it would be a "mercy from heaven," he said.

In 2002, the Iraqi health budget was $\$ 16 \mathrm{~m}$ for a population of 22 million. In 2003, the ministry spent $\$ 245 \mathrm{~m}$ and this year the health budget is $\$ 950 \mathrm{~m}$.

Dr Abbas said that even though the level of health care is better now than in 2003 and before that, he is still under immense pressure to deliver.

"Our people have suffered a lot; they've lost patience and they want everything done yesterday. But as managers, we know this can take time," he said.

While a computerised medicines register is being installed and the ministry is creating a modern mental health system from scratch, one of the greatest health problems in Iraq remains the most basic: the unreliability of clean water and power supplies.

Leaving his wife and five children behind in Britain was a "sacrifice" that Dr Abbas said he had to make. "I owe it to my country. I have to do my part in the work, lay a foundation, and hand over to whoever will follow me."

As a member of Iraq's interim ministerial council, Dr Abbas's position is perhaps not as exposed and therefore not as risky as those on its governing council-the president of which, Izzedine Salim, was assassinated this month.

What happens after the handover of power to the Iraqi people at the end of June is still unclear, but there is no doubt that Dr Abbas is determined to help transform Iraq into a democratic country.

Fiona Fleck Geneva 